\title{
MTHFR C677T polymorphism and differential methylation status in gastric cancer: an association with Helicobacter pylori infection
}

\author{
Eduardo Henrique Cunha Neves Filho • \\ Markenia Kelia Santos Alves • Valeska Portela Lima • \\ Silvia Helena Barem Rabenhorst
}

Received: 25 June 2010 /Revised: 1 October 2010 / Accepted: 5 October 2010 / Published online: 19 October 2010

(C) Springer-Verlag 2010

\begin{abstract}
MTHFR C677T and Helicobacter pylori infection are believed to play critical roles in the DNA methylation process, an epigenetic feature frequently found in gastric cancer. The aim of this study was to verify the associations between the MTHFR C677T polymorphism and the methylation status of three gastric cancer-related genes. The influence of $H$. pylori strains was also assessed. DNA extracted from 71 gastric tumor samples was available for MTHFR C677T genotyping by PCR-RFLP, promoter methylation identification by MS-PCR and $H$. pylori detection and posterior subtyping (cagA and vacA genes) by PCR. In the distal tumors, a positive correlation was found between the methylation of $C D K N 2 A$ and the allele T carriers $(r=0.357 ; p=0.009)$. Considering the eldest patients (age $\geq 60$ years old), this correlation was even higher $(r=0,417 ; p=0.014)$. H. pylori infection by highly pathogenic strains (cagA+/vacAs1m1) was also found correlated to promoter methylation of $C D K N 2 A$ and the allele $\mathrm{T}$ carriers in distal tumors $(r=0.484 ; p=0.026)$. No significant correlation was verified between MTHFR C677T genotype and promoter methylation status when
\end{abstract}

E. H. C. Neves Filho • M. K. S. Alves • V. P. Lima

S. H. B. Rabenhorst

Department of Pathology and Forensic Medicine-Genetic

Section, Universidade Federal do Ceará,

Rua Alexandre Baraúna, 949, Porangabussu,

CEP 60183-630 Fortaleza, Brazil

E. H. C. Neves Filho $(\square)$

Departamento de Patologia e Medicina Legal,

Universidade Federal do Ceará-Faculdade de Medicina,

Rua Alexandre Baraúna, 949, Porangabussu,

CEP 60183-630 Fortaleza, CE, Brazil

e-mail: edu0689@yahoo.com.br we analyzed the general sample. DNA methylation in CDKN2A associated to the MTHFR 677T carrier is suggested to be a distal tumor characteristic, especially in those 60 years old or older, and it seems to depend on the infection by $H$. pylori cagA/vacAs1m1 strains.

Keywords MTHFR C677T . DNA methylation · Helicobacter pylori. Gastric cancer

\section{Introduction}

Gastric adenocarcinoma is one of the most frequent malignancies worldwide and it is globally the second leading cause of cancer-related deaths [1]. Brazil is one of the countries with a higher incidence, mainly in the Southeast and Northeast regions [2]. Gastric cancer has multifactorial etiology, being caused by environmental, genetic and epigenetic factors, which may interact to the tumor promotion and progression [3]. Epidemiological studies have shown an association between disturbances of folate metabolism and increased risk of gastric cancer, including low intake of folate, low levels of folate in blood or genetic factors affecting folate metabolism, such as polymorphisms in folate-metabolizing genes [4-6].

Methylenetetrahydrofolate reductase (MTHFR) acts centrally in folate metabolism, catalyzing the 5methylenetetrahydrofolate synthesis reaction, the predominant circulatory form of folate and carbon donor for the remethylation of homocysteine to methionine. This pathway leads to the production of $S$-adenosylmethionine, the universal donor of methyl radical in human, which is required for DNA methylation [7]. Thus, polymorphisms that reduce the MTHFR activity could influence the status of DNA 
methylation and would explain individual susceptibility to gastric cancer [8]. A C/T nucleotide change at 677 position of the MTHFR gene (MTHFR C677T), resulting in an alanine-to-valine substitution in the MTHFR protein, was found to produce a thermolabile variant of the MTHFR and significantly reduces the enzyme activity [9]. Furthermore, a recent meta-analysis carried out by Boccia et al. reported a significant positive correlation between gastric cancer and the MTHFR 677TT genotype [10].

DNA methylation is an important epigenetic feature of DNA that plays critical roles in gene regulation and cellular differentiation mechanisms. Methylation of promoter, especially in the $\mathrm{CpG}$ islands, culminates in gene silencing. Gastric cancer is one of the human tumors with higher number of silenced genes by methylation of their $\mathrm{CpG}$ islands [11]. Currently, the available data about the role of MTHFR C677T polymorphism in relation to the aberrant DNA methylation in gastric cancer is inconsistent and incomplete. It has been suggested that this polymorphism plays a dual role on the methylation status of promoter regions depending on the target gene $[8,12]$.

Another important etiological factor in gastric cancer is Helicobacter pylori infection. Bacterial virulence factors are characteristics present in some bacteria which enable them to cause disease. These are, mainly, vacuolating cytotoxin production associated to certain types of $\mathrm{vacA}$ (vacuolating cytotoxin gene $\mathrm{A}$ ) alleles and $\operatorname{cag} A$ (cytotoxin associated gene product A) [13]. H. pylori strains expressing $\operatorname{cag} A$ and more active forms of vacA, such as the $\mathrm{s} 1 \mathrm{~m} 1$ genotype, are more likely to cause disease [14].

Despite of some advances, the molecular mechanisms associated with $H$. pylori in gastric carcinogenesis remains poorly understood. One of the promoting effects has been attributed to the induction of inflammation and aberrant methylation. It has been reported that frequencies or levels of $\mathrm{CpG}$ islands methylation of certain genes correlate with H. pylori infection, histological or serological severity of gastritis, and gastric cancer occurrence [12]. The observation that $H$. pylori-induced methylation is reversed after $H$. pylori eradication therapy supports this hypothesis [14]. Thus, the aim of this study was to verify the associations between the MTHFR C677T polymorphism genotype and the DNA methylation of three candidates genes $(C O X-2, C D K N 2 A$, and $H M L H 1$ ), largely associated with gastric carcinogenesis, and the influence of $H$. pylori strains in this process.

\section{Materials and methods}

\section{Clinical specimens}

The present study was approved by the Hospital Ethics Committee in the Federal University of Ceará and all subjects signed the informed consent form before inclusion. Samples from 71 patients with gastric adenocarcinoma who had undergone gastrectomy were collected from Walter Cantídio University Hospital and Santa Casa de Misericórdia Hospital, both located in Fortaleza, the Ceará state capital. The histological classification was done according to Lauren's classification by our team of pathologists.

\section{DNA extraction}

Genomic DNA was extracted from frozen tumor tissue using the cetyltrimethyl ammonium bromide (CTAB) technique, adapted from Foster and Twell [15]. The DNA extraction was done only in fragments that showed more than $80 \%$ of tumor cells. The DNA quality was analyzed by $1 \%$ agarose gel electrophoresis and the amount was determined using the NanoDropTM ${ }^{\circledR} 3300$ fluorospectrometer (Wilmington, DE, USA).

Sodium bisulfite treatment and methylation-specific PCR (MS-PCR)

Extracted DNA of tumor tissue was modified by sodium bisulfite to determine the methylation status of the $C D K N 2 A, H M L H 1$, and $C O X-2$ genes by MS-PCR, as previously described by Ferrasi et al. [16]. The primers targeted to the studied promoter gene regions are described in Table 1. PCR was performed in $25 \mu \mathrm{L}$ reaction volume, containing $1 \times$ Platinum Taq buffer, $3.0 \mathrm{mM} \mathrm{MgCl}_{2}$ $(C D K N 2 A)$ or $1.5 \mathrm{mM} \mathrm{MgCl}_{2}$ (HMLH1 and COX-2), $0.4 \mathrm{mM}$ of each dNTPs, $0.64 \mu \mathrm{M}(C D K N 2 A), 0.24 \mathrm{mM}$ (HMLH1) or $0.4 \mathrm{mM}(C O X-2)$ of each primer set, $1 \mathrm{U}$ of Platinum Taq DNA Polymerase ${ }^{\circledR}$ (Invitrogen, Foster, CA, USA), and $1 \mu \mathrm{L}$ of treated DNA. DNA methylated in vitro by Sss-I methylase ${ }^{\circledR}$ (New England Biolabs, Beverly, MA, USA) was used as a positive control. Water and DNA from peripheral lymphocytes of healthy donors were used as negative controls. The PCR products were separated in $6 \%$ non-denaturing polyacrylamide gel and subsequently submitted to silver staining (Fig. 1).

For confirmation of the reaction specificity, MS-PCR products from $C D K N 2 A, H M L H 1$, and $C O X-2$ genes analyzed were cloned with a TOPO TA Cloning $\mathrm{Kit}^{\circledR}$ (Invitrogen, California, USA) and both the methylated and unmethylated PCR products were sequenced using an ABI PRISM $^{\circledR}$ BigDye Terminator v.3.0 Cycle Sequencing Kit ${ }^{\circledR}$ (Applied Biosystems, Foster, CA, USA) and ABI Prism 3100 DNA Sequencer ${ }^{\circledR}$ (Applied Biosystems).

Determination of MTHFR C677T genotypes

MTHFR C677T genetic polymorphism was detected by PCR-RFLP as previously described by Frosst et al. [17]. 
Table 1 PCR primer sets used for MS-PCR

\begin{tabular}{|c|c|c|c|c|c|}
\hline \multirow[t]{2}{*}{ Gene } & \multicolumn{2}{|l|}{ Primer sequences $\left(5^{\prime}-3^{\prime}\right)$} & \multirow[t]{2}{*}{ Annealing $\left({ }^{\circ} \mathrm{C}\right)$} & \multirow{2}{*}{$\begin{array}{l}\text { Size of PCR } \\
\text { product (bp) }\end{array}$} & \multirow[t]{2}{*}{ Ref. } \\
\hline & Forward & Reverse & & & \\
\hline \multirow[t]{2}{*}{$C D K N 2 A$} & M TTATTAGAGGGTGGGGCGGATCGC & GACCCCGAACCGCGACCGTAA & 70 & 150 & \multirow[t]{2}{*}[32]{} \\
\hline & U TTATTAGAGGGTGGGGTGGATTGT & CAACCCCAAACCACAACCATAA & 70 & 151 & \\
\hline \multirow[t]{2}{*}{$H M L H 1$} & M TATATCGTTCGTAGTATTCGTGT & TCCGACCCGAATAAACCCAA & 66 & 153 & \multirow[t]{2}{*}[33]{} \\
\hline & $\begin{array}{l}\text { U TTTTGATGTAGATGTTTTATTAG } \\
\text { GGTTGT }\end{array}$ & ACCACCTCATCATAACTACCCACA & 64 & 124 & \\
\hline \multirow[t]{2}{*}{$C O X-2$} & M TTAGATACGGCGGCGGCGGC & TCTTTACCCGAACGCTTCCG & 59 & 161 & \multirow[t]{2}{*}[34]{} \\
\hline & U ATAGATTAGATATGGTGGTGGTGGT & CACAATCTTTACCCAAACACTTCCA & 65 & 171 & \\
\hline
\end{tabular}

$M$ methylated; $U$ unmethylated

The PCR products of 198 bp were digested with restriction endonuclease $\operatorname{Hinf} \mathrm{I}$, producing a 175 and a $23 \mathrm{bp}$ fragments if the polymorphism was present. The digestive products were resolved by electrophoresis in $6 \%$ polyacrylamide gel with silver staining. Random samples were reanalyzed for laboratory procedures control (Fig. 2).

Detection of $H$. pylori and vacA alleles and the presence of cagA gene

H. pylori infection was detected by PCR of the ureC gene. The primers for the $H$. pylori studied genes and their annealing temperature are described in Table 2. For confirmation of the reaction specificity, PCR products from ure $\mathrm{C}$ gene were cloned with TOPO TA Cloning $\mathrm{Kit}^{\circledR}$ (Invitrogen, California, USA) and sequenced using the ABI PRISM $^{\circledR}$ BigDye Terminator v.3.0 Cycle Sequencing Kit ${ }^{\circledR}$

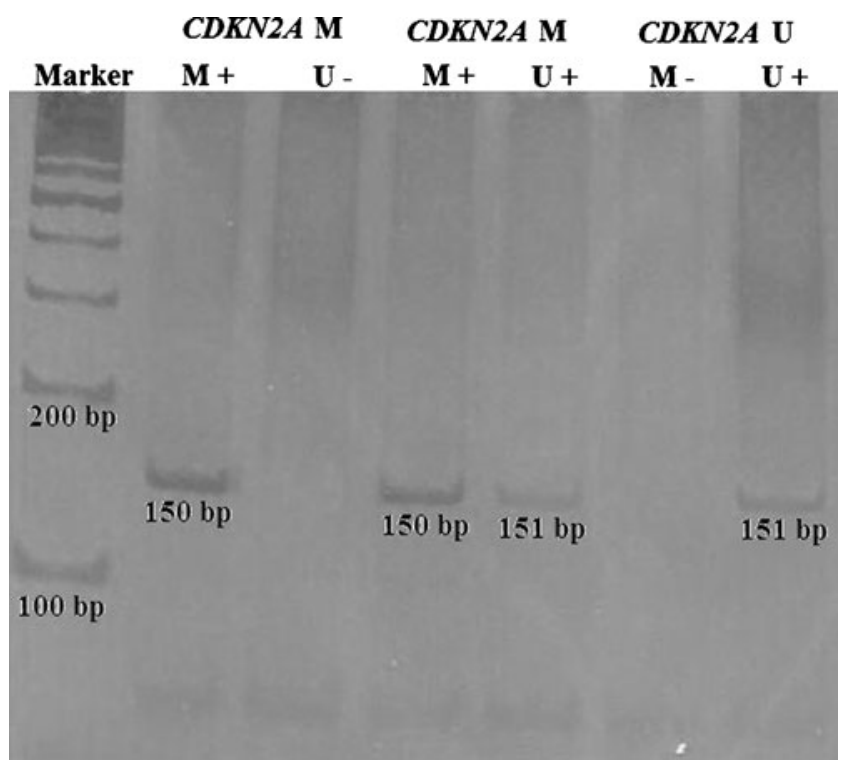

Fig. 1 Representative electrophoresis of the CDKN2A MS-PCR in $6 \%$ polyacrylamide gel with silver staining
(Applied Biosystems, Foster, CA, USA) and ABI Prism 3100 DNA Sequencer ${ }^{\circledR}$ (Applied Biosystems).

The ure $, \operatorname{cagA}, \operatorname{vac} \mathrm{A} \mathrm{s} 1 / \mathrm{s} 2, v a c \mathrm{~A} \mathrm{~m} 1 / \mathrm{m} 2$ genes were amplified in a $25-\mu \mathrm{L}$ volume containing $2.5 \mu \mathrm{L}$ of $10 \times$ PCR buffer ${ }^{\circledR}$ (Invitrogen, Cergy Pontoise, France); 1\% Tween 20, $1.5 \mathrm{mM}$ of $\mathrm{MgCl}_{2}$ (Invitrogen), $200 \mu \mathrm{M}$ (each) of dNTPs (Invitrogen), 1U of Platinum Taq polymerase ${ }^{\circledR}$ (Invitrogen); $0.4 \mu \mathrm{M}$ (ureC, cagA, vacA s1/s2, vacA m1), $0.3 \mu \mathrm{M}($ vacA $\mathrm{m} 2)$ for each primer and $1 \mu \mathrm{L}$ of DNA. DNAse-free water was used as negative control. The PCR products were analyzed by $1 \%$ agarose gel electrophoresis with ethidium bromide staining (Fig. 3). vacA and cagA genes were considered positive when a specific fragment was detected (Table 2). Random samples were reanalyzed to confirm the results. DNA preservation has been confirmed by amplification of different genes in other approaches under study in our laboratory.

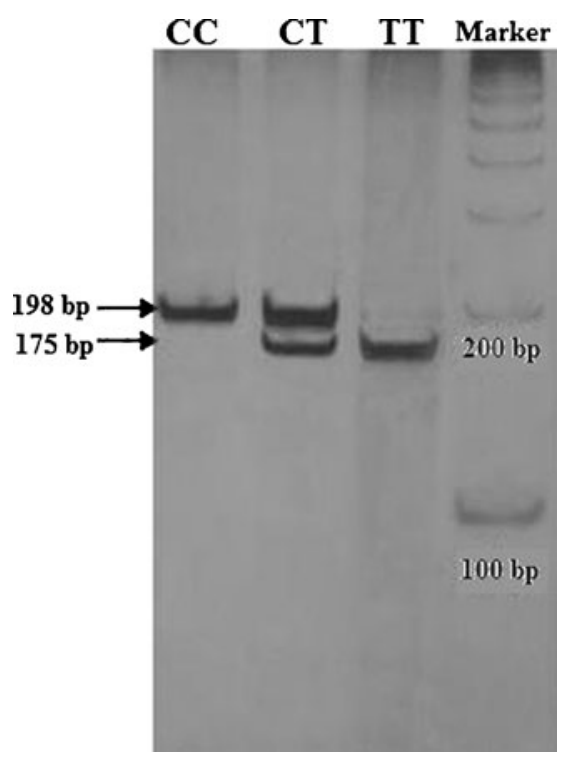

Fig. 2 Representative electrophoresis of the MTHFR C677T polymorphism in $6 \%$ polyacrylamide gel with silver staining 
Fig. 3 Representative electrophoresis of the ure $\mathrm{C}$ and $\operatorname{cagA}$ genes amplification in $6 \%$ polyacrylamide gel with silver staining

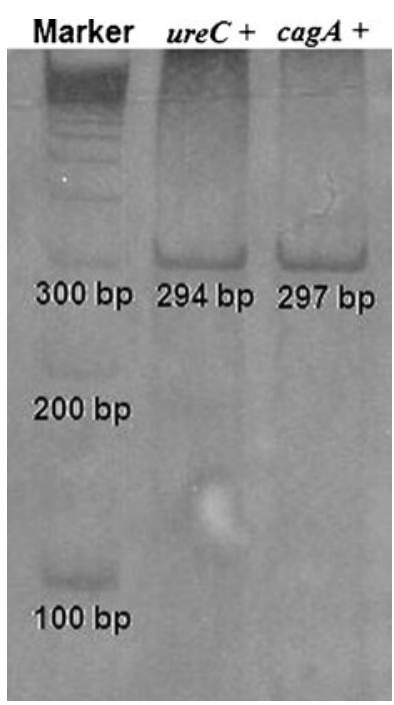

Statistical analyses

These were carried out using the statistical program SPSS ${ }^{\circledR}$ version 15.0 (Chicago, IL, USA). Statistically significant differences were evaluated by the chi-square test $\left(\chi^{2}\right)$. Correlations were analyzed by Spearman's rank correlation coefficient. The results were considered statistically significant when $p$ values were less than 0.05 .

\section{Results}

Study population

Among the 71 cases analyzed, 45 (63.4\%) were males and $26(36.6 \%)$ females. The average age was 64.2, ranging from 23 to 92 years old. The most frequent site was the gastric non cardia [52/71 $(73.2 \%) \times 19 / 71(26.8 \%)]$. Intestinal and diffuse subtypes presented $43(60.5 \%)$ and 28 (39.5\%) frequencies, respectively.
Frequency of promoter methylation of three $\mathrm{CpG}$ islands and MTHFR genotypes

All 71 tumor samples were available for MS-PCR analysis and for MTHFR genotyping. CpG island methylation was found in 30 of the tumors samples $(42.2 \%)$ for $C D K N 2 A$, $38(53.5 \%)$ for $C O X-2$ and $22(30.9 \%)$ for HMLH1. The MTHFR C677T genotype shows similar frequency for the homozygous CC $(34 / 71 ; 47.8 \%)$ and heterozygous CT (31/ $71 ; 43.6 \%$ ) carriers. Homozygous carries for MTHFR 677TT was found in only $8.6 \%$ of the patients.

Association between MTHFR C677T, promoter methylation and clinicopathological parameters

The association of each MTHFR C677T genotype to the promoter $\mathrm{CpG}$ islands methylation status is shown in Table 3. No significant correlation was found between the promoter methylation for all the studied genes, age (cutoff of 60 years old), histological subtypes (intestinal and diffuse), and MTHFR genotype (Table 3).

When the tumors were analyzed according to its localization, in the distal tumors a positive correlation was found between the promoter methylation of $C D K N 2 A$ and the allele T carriers (CT and TT genotypes; $r=0.357$, $p=0.009$ ) (Table 4). Considering the patients age with 60 years old or older, this correlation was even higher $(r=0.417, p=0.014)$.

Influence of $H$. pylori genotype in the methylation process

H. pylori infection was present in 68 of the patients (95.8\%). Among them, 31 (45.5\%) were $\operatorname{cag} A+/ v a c A \mathrm{~s} 1 \mathrm{~m} 1$. As most of the patients were $H$. pylori positive, we verify if there was an association between the H. pylori strains and the MTHFR genotype in gene methylation, considering clinicopathological parameters. From these analysis, we

Table 2 PCR primer sets used for genotyping H. pylori

\begin{tabular}{|c|c|c|c|c|}
\hline Gene & Primer sequence & Annealing $\left({ }^{\circ} \mathrm{C}\right)$ & Size (bp) of PCR product & Reference number \\
\hline ureC & $\begin{array}{l}\mathrm{F}-5^{\prime} \text { AAGCTTTTAGGGGTGTTAGGGGTTT 3' } \\
\mathrm{R}-5^{\prime} \text { AAGCTTACTTTCTAACACTAACGC 3' }\end{array}$ & 55 & 294 & [35] \\
\hline \multicolumn{5}{|l|}{$v a c A$} \\
\hline $\mathrm{s} 1 / \mathrm{s} 1$ & $\begin{array}{l}\mathrm{F}-5^{\prime} \text { ATGGAAATACAACAAACACAC } 3^{\prime} \\
\mathrm{R}-5^{\prime} \text { CTGCTTGAATGCGCCAAAC } 3^{\prime}\end{array}$ & 55 & $259 / 286$ & {$[36]$} \\
\hline $\mathrm{m} 1$ & $\begin{array}{l}\mathrm{F}-5^{\prime} \text { GGTCAAAATGCGGTCATGG 3' } \\
\mathrm{R}-5^{\prime} \text { CCATTGGTACCTGTAGAAAC } 3^{\prime}\end{array}$ & 55 & 290 & \\
\hline $\mathrm{m} 2$ & $\begin{array}{l}\mathrm{F}-5^{\prime} \text { GGAGCCCCAGGAAACATTG 3' } \\
\mathrm{R}-5^{\prime} \text { CATAACTAGCGCCTTGCAC 3' }\end{array}$ & 52 & 192 & \\
\hline $\operatorname{cag} A$ & $\begin{array}{l}\mathrm{F}-5^{\prime} \text { ATAATGCTAAATTAGACAACTTGAGCGA } 3^{\prime} \\
\mathrm{R}-5^{\prime} \text { TTAGAATAATCAACAAACATAACGCCAT } 3^{\prime}\end{array}$ & 56 & 297 & {$[37]$} \\
\hline
\end{tabular}

$F$ forward; $R$ reverse 
Table 3 Association between the MTHFR C677T genotype, the clinicopathological parameters, and the promoter methylation status for the three studied genes

\begin{tabular}{|c|c|c|c|c|}
\hline \multirow[t]{2}{*}{ Variables } & \multicolumn{3}{|c|}{ MTHFR genotype } & \multirow[t]{2}{*}{ Alelle $\mathrm{T}$ carriers } \\
\hline & $\mathrm{CC}$ & $\mathrm{CT}$ & TT & \\
\hline \multicolumn{5}{|l|}{ Sex } \\
\hline Male & 22 & 18 & 5 & 23 \\
\hline Female & 12 & 13 & 1 & 14 \\
\hline \multicolumn{5}{|l|}{ Age } \\
\hline$<60$ & 13 & 7 & 2 & 9 \\
\hline$\geq 60$ & 21 & 24 & 4 & 28 \\
\hline \multicolumn{5}{|c|}{ Lauren's histotype } \\
\hline Diffuse & 13 & 13 & 2 & 15 \\
\hline Intestinal & 21 & 18 & 4 & 22 \\
\hline \multicolumn{5}{|l|}{ Anatomical site } \\
\hline Proximal & 9 & 8 & 2 & 10 \\
\hline Distal & 25 & 23 & 4 & 27 \\
\hline \multicolumn{5}{|l|}{$C D K N 2 A$} \\
\hline Methylated & 23 & 15 & 3 & 18 \\
\hline Unmethylated & 11 & 16 & 3 & 19 \\
\hline \multicolumn{5}{|l|}{$C O X-2$} \\
\hline Methylated & 17 & 13 & 3 & 16 \\
\hline Unmethylated & 17 & 18 & 3 & 21 \\
\hline \multicolumn{5}{|l|}{$H M L H 1$} \\
\hline Methylated & 24 & 21 & 4 & 25 \\
\hline Unmethylated & 10 & 10 & 2 & 12 \\
\hline
\end{tabular}

found a high association between the promoter methylation of CDKN2A and the MTHFR 677T carrier $(r=0.484, p=$ $0.026)$ in the distal tumors infected by H. pylori cagA+/ vacAs $1 \mathrm{~m} 1$.

Association between number of methylated $\mathrm{CpG}$ islands and MTHFR genotype

To investigate whether the MTHFR genotype might be associated with methylation of multiple $\mathrm{CpG}$ sites we grouped all the 71 subjects according to the numbers of methylated genes: none, 1,2 , and 3 . No promoter methylated gene was present in $20(28.2 \%)$ of the cases while the presence of 1,2 , and 3 was observed in 19 $(26.8 \%), 25(35.2 \%)$, and $7(9.8 \%)$ of the cases, respectively. The mean number of methylated $\mathrm{CpG}$ sites according to the MTHFR genotype was 1.12 for CC, 1.42 for $\mathrm{CT}, 1.33$ for $\mathrm{TT}$ and 1.40 for $\mathrm{T}$ carrier. No significant association was found between MTHFR genotype and number of methylated $\mathrm{CpG}$ sites and no statistical difference was verified between the number mean of methylated $\mathrm{CpG}$ sites over the different MTHFR genotypes.

\section{Discussion}

The relationship between the hypermethylation of tumor suppressor genes or DNA repair genes with the gastric carcinogenesis process has been pointed in many studies; however, the factors involved in the induction of this process are still unknown $[18,19]$. Some studies indicate that DNA methylation depends on environmental factors such as $H$. pylori infection and may also vary according to the presence of polymorphisms involved in this process as those of enzymes involved in the folate cycle $[8,12,13]$. However, there are only few studies focusing these aspects and they present controversial results. So that, in the present study, the association between the methylation status of CDKN2A, HMLH1, and COX-2, the MTHFR C677T polymorphism and the influence of high pathogenic $H$. pylori strains in gastric cancer were analyzed.

The first analysis focused the association between the presence of promoter methylation and the MTHFR C677T polymorphism. Some studies demonstrated that genetic and epigenetic changes in gastric carcinoma differ depending on the tumor localization and on its histological subtype $[20,21]$. Based on that, the data were analyzed according to these aspects. Although no difference was observed regarding to histological subtype, differences were identified according to the tumor anatomic site. In the distal tumors, an unexpected positive correlation was found between the $\mathrm{CpG}$ island methylation of $C D K N 2 A$ and the allele $\mathrm{T}$ carriers. In fact, this correlation was even higher when we considered the 60 years old or older patients. Tahara et al. [12] also observed a similar correlation between the hypermethylation of CDKN2A and the MTHFR 677TT genotype, but these authors did not associate it to the tumor anatomic site. Both ours and Tahara et al.'s studies disagree with Weng et al. [22],

Table 4 Association between MTHFR polymorphism and methylation status of three promoter $\mathrm{CpG}$ islands on the distal tumors

\begin{tabular}{|c|c|c|c|c|}
\hline \multirow[t]{2}{*}{ Variables } & \multicolumn{3}{|c|}{ MTHFR genotype } & \multirow[t]{2}{*}{ Alelle $\mathrm{T}$ carriers } \\
\hline & $\mathrm{CC}$ & $\mathrm{CT}$ & TT & \\
\hline \multicolumn{5}{|l|}{$C D K N 2 A$} \\
\hline Unmethylated & 6 & 14 & 2 & 16 \\
\hline Methylated & 9 & 9 & 2 & $11^{*}$ \\
\hline \multicolumn{5}{|l|}{$C O X-2$} \\
\hline Unmethylated & 13 & 14 & 2 & 16 \\
\hline Methylated & 12 & 9 & 2 & 11 \\
\hline \multicolumn{5}{|l|}{$H M L H 1$} \\
\hline Unmethylated & 10 & 9 & 1 & 10 \\
\hline Methylated & 15 & 14 & 3 & 17 \\
\hline
\end{tabular}

$* p=0.009$ 
which found a promoter hypermethylation of $C D K N 2 A$ in patients with the MTHFR $677 \mathrm{CC}$ genotype. Various studies have been associating the MTHFR C677T polymorphism to gastric cancer risk in a specific anatomic localization. Wang et al. [23], evaluating the association of MTHFR C677T and thymidylate synthase promoter polymorphisms with genetic susceptibility found a gastric cardia adenocarcinoma risk related to the MTHFR 677TT and 2R2R genotypes. Likewise, Miao et al. [5] observed that subjects with the MTHFR 677TT variant genotype had a twofold increased risk of gastric cardia adenocarcinoma. These studies suggested that the common functionally polymorphism MTHFR C677T plays a substantial influence in the gastric cardia adenocarcinoma carcinogenesis. However, both studies did not evaluate the methylation pattern of specific genes associated to this polymorphism. Related to methylation status associated with tumor region there are some controversy. Vo et al. [24] found no distinct methylation status for $C D K N 2 A$ regarded to the tumor localization, while recent studies carried out in Turkey [25] and Germany [26] correlate methylation of promoter $C D K N 2 A$ to cardiac tumors, but the MTHFR C677T polymorphism influence was not assessed. We suggest that in distal tumors, the silencing of tumor suppressor genes by their promoter $\mathrm{CpG}$ islands methylation, especially when influenced by MTHFR polymorphism, might be an important carcinogenic pathway.

It has been well established over the literature that, in general, the methylation status of promoter $\mathrm{CpG}$ islands tends to increase with age [27]. From that standpoint, we found that the correlation between methylation of $C D K N 2 A$ and MTHFR 677T carrier subjects in distal tumors is higher in an older generation (60 years old or older). It seems that the MTHFR polymorphism may have a greater influence on the methylation status as time goes by. Additionally, in the present study, MTHFR C677T polymorphism does not act homogeneously over all the studied genes. MTHFR 677TT genotype seems to be related to the hypermethylation of $C D K N 2 A$; on the other hand, it does not show an involvement regarding to $H M L H 1$ and $C O X-2$ methylation status. Some studies have been reporting this dual behavior of MTHFR C677T polymorphism regarding to methylation or unmethylation of promoter regions depending on the target gene $[8,12]$. Our data suggests that this differential methylation status influenced by MTHFR C677T genotype depends on the tissue, specifically on the tumor localization. Probably the induction of the methylation process of some genes, like HMLH1 and $C O X-2$, is independent on the MTHFR C677T polymorphism.

Although the hypermethylation of promoter regions in genes involved on gastric carcinogenesis has been well accepted and some studies associate it with MTHFR C677T polymorphism, the influence of $H$. pylori in this process is still not understood. In the present study, the infection by a highly pathogenic $H$. pylori strain (cagA+and vacA s $1 \mathrm{~m} 1$ genotype) was associated to the methylation of $C D K N 2 A$ in the distal stomach in patients with MTHFR 677TT genotype.

Recently, there have been reports showing that $H$. pylori infection is the most predisposing factor for gene methylation in the stomach [28-30]. It is well known that $H$. pylori induces chronic inflammation, resulting in downregulation of the some genes that maintain gastric mucosal homeostasis [14]. Also, the inflammation induced by $H$. pylori infection seems to promoter methylation of certain genes [31], which could justify an increased risk of tumor formation, mainly associated with the risk of noncardia gastric cancer.

In conclusion, the DNA methylation in promoter regions of CDKN2A associated to the MTHFR 677T carrier is suggested to be a distal tumor characteristic, especially in those 60 years old or older, and depends on the infection by H. pylori cagA/vacAs1m1 strains. More studies with large sample size involving the folate enzymes polymorphisms, DNA methylation and $H$. pylori infection are needed to extend our understanding of gastric carcinogenesis.

Conflict of interest statement We attest the inexistence of conflicts of interest, corporate involvement, or patent holdings.

\section{References}

1. Lao-Sirieix P, Caldas C, Fitzgerald RC (2010) Genetic predisposition to gastro-oesophageal cancer. Curr Opin Genet Dev 20 (3):210-217

2. Ministério da Saúde do Brasil. Instituto Nacional de Câncer (2009) Estimativa 2010: incidência de câncer no Brasil. INCA, Rio de Janeiro

3. Cotran RS et al (2000) Robbins-patologia estrutural e funcional. Guanabara Koogan, Rio de Janeiro

4. Choi SW, Mason JB (2000) Folate and carcinogenesis: an integrated scheme. J Nutr 130:129-132

5. Miao X, Xing D, Tan W, Qi J, Lu W, Lin D (2002) Susceptibility to gastric cardia adenocarcinoma and genetic polymorphism in methylenetetrahydrofolate reductase in an at-risk Chinese population. Cancer Epidemiol Biomark Prev 11(11):1454-1458

6. Götze T, Röcken C, Röhl FW et al (2007) Gene polymorphisms of folate metabolizing enzymes and the risk of gastric cancer. Cancer Lett 251(2):228-236

7. Shen $\mathrm{H}, \mathrm{Xu} \mathrm{Y}$, Zheng Y et al (2001) Polymorphisms of 5, 10methylenetetrahydrofolate reductase and risk of gastric cancer in a Chinese population: a case-control study. Int J Cancer 5:332-336

8. Wang J, Sasco AJ, Fu C et al (2008) Aberrant DNA methylation of P16, MGMT, and hMLH1 genes in combination with MTHFR C677T genetic polymorphism in esophageal squamous cell carcinoma. Cancer Epidemiol Biomark Prev 17(1):118-125

9. Graziano F, Kawakami K, Ruzzo A et al (2006) Methylenetetrahydrofolate reductase $677 \mathrm{C} / \mathrm{T}$ gene polymorphism, gastric cancer susceptibility and genomic DNA hypomethylation in an at-risk Italian population. Int J Cancer 118(3):628-632 
10. Boccia S, Hung R, Ricciardi G et al (2008) Meta- and pooled analyses of the methylenetetrahydrofolate reductase C677T and A1298C polymorphisms and gastric cancer risk: a huge-GSEC review. Am J Epidemiol 167(5):505-516

11. Perri F, Cotugno R, Piepoli A et al (2007) Aberrant DNA methylation in non-neoplastic gastric mucosa of $H$. pylori infected patients and effect of eradication. Am J Gastroenterol 102 (7):1361-1371

12. Tahara T, Shibata T, Nakamura M et al (2009) MTHFR 677T carrier influences the methylation status of $H$. pylori-infected gastric mucosa in older subjects. Dig Dis Sci 54(11):2391-2398

13. Atherton JC (1998) H. pylori virulence factors. Br Med Bull 54 (1): $105-120$

14. Atherton JC (2006) The pathogenesis of Helicobacter pyloriinduced gastro-duodenal diseases. Annu Rev Pathol 1:63-96

15. Foster GD, Twell DJ (1996) Plant gene isolation: principles and practice. Wiley, England

16. Ferrasi AC, Pinheiro NA, Rabenhorst SH et al (2010) Helicobacter pylori and EBV in gastric carcinomas: methylation status and microsatellite instability. World J Gastroenterol 16(3):312-319

17. Frosst P, Blom HJ, Milos R et al (1995) A candidate genetic risk factor for vascular disease: a common mutation in methylenetetrahydrofolate reductase. Nat Genet 10:111-113

18. Kim H, Kim YH, Kim SE, Kim NG, Noh SH, Kim H (2003) Concerted promoter hypermethylation of hMLH1, p16INK4A, and E-cadherin in gastric carcinomas with microsatellite instability. J Pathol 200(1):23-31

19. Shim YH, Kang GH, Ro JY (2000) Correlation of p16 hypermethylation with p16 protein loss in sporadic gastric carcinomas. Lab Invest 80(5):689-695

20. Driessen A, Nafteux P, Lerut $T$ et al (2004) Identical cytokeratin expression pattern $\mathrm{CK} 7+/ \mathrm{CK} 20-$ in esophageal and cardiac cancer: etiopathological and clinical implications. Mod Pathol 17 (1):49-55

21. Tahara E (2004) Genetic pathways of two types of gastric cancer. IARC Sci Publ 157:327-349

22. Weng YR, Sun DF, Fang JY, Gu WQ, Zhu HY (2006) Folate levels in mucosal tissue but not methylenetetrahydrofolate reductase polymorphisms are associated with gastric carcinogenesis. World J Gastroenterol 12(47):7591-7597

23. Wang LD, Guo RF, Fan ZM et al (2005) Association of methylenetetrahydrofolate reductase and thymidylate synthase promoter polymorphisms with genetic susceptibility to esophageal and cardia cancer in a Chinese high-risk population. Dis Esophagus 18(3):177-184

24. Vo QN, Geradts J, Boudreau DA, Bravo JC, Schneider BG (2002) CDKN2A promoter methylation in gastric adenocarcinomas: clinical variables. Hum Pathol 33(12):1200-1204
25. Ksiaa F, Ziadi S, Amara K, Korbi S, Trimeche M (2009) Biological significance of promoter hypermethylation of tumorrelated genes in patients with gastric carcinoma. Clin Chim Acta 404(2):128-133

26. Sarbia M, Geddert H, Klump B, Kiel S, Iskender E, Gabbert HE (2004) Hypermethylation of tumor suppressor genes (p16INK4A, p14ARF and APC) in adenocarcinomas of the upper gastrointestinal tract. Int J Cancer 111(2):224-228

27. van Rijnsoever M, Grieu F, Elsaleh H, Joseph D, Iacopetta B (2002) Characterisation of colorectal cancers showing hypermethylation at multiple $\mathrm{CpG}$ islands. Gut 51(6):797-802

28. Nardone G, Compare D, De Colibus P, de Nucci G, Rocco A (2007) Helicobacter pylori and epigenetic mechanisms underlying gastric carcinogenesis. Dig Dis 25(3):225-229

29. Kitajima Y, Ohtaka K, Mitsuno M et al (2008) Helicobacter pylori infection is an independent risk factor for Runx 3 methylation in gastric cancer. Oncol Rep 19(1):197-202

30. Maekita T, Nakazawa K, Mihara M et al (2006) High levels of aberrant DNA methylation in Helicobacter pylori-infected gastric mucosae and its possible association with gastric cancer risk. Clin Cancer Res 12(3 Pt 1):989-995

31. Katayama Y, Takahashi M, Kuwayama H (2009) Helicobacter pylori causes runx 3 gene methylation and its loss of expression in gastric epithelial cells, which is mediated by nitric oxide produced by macrophages. Biochem Biophys Res Commun 388(3):496500

32. Herman JG, Graff JR, Myöhänen S, Nelkin BD, Baylin SB (1996) Methylation-specific PCR: a novel PCR assay for methylation status of CpG islands. Proc Natl Acad Sci 93:9821-9826

33. Kang GH, Shim YH, Ro JY (1999) Correlation of methylation of the HMLH1 promoter with lack of expression of HMLH1 in sporadic gastric carcinomas with replication error. Lab Invest 79 (7):903-909

34. Akhtar M, Cheng Y, Magno RM et al (2001) Promoter methylation regulates Helicobacter pylori-stimulated cyclooxygenase-2 expression in gastric epithelial cells. Cancer Res 61(6):2399-2403

35. Lage AP, Godfroid E, Fauconnier A et al (1995) Diagnosis of Helicobacter pylori infection by PCR: comparison with other invasive techniques and detection of cagA gene in gastric biopsy specimens. J Clin Microbiol 33:2752-2756

36. Atherton JC, Cao P, Peek RMJR, Tummuru MK, Blaser MJ, Cover TL (1995) Mosaicism in vacuolating cytotoxin alleles of Helicobacter pylori. Association of specific vacA types with cytotoxin production and peptic ulceration. J Biol Chem 270:17771-17777

37. Domingo D, Alarcon T, Pietro N, Sanchez I, Lopez-Brea M (1999) cagA and vacA status of Spanish Helicobacter pylori clinical isolates. J Clin Microbiol 37:2113-2114 